\title{
Violence: The church is part of the problem
}

\begin{tabular}{|c|}
\hline $\begin{array}{l}\text { Author: } \\
\text { Erna Oliver }{ }^{1}\end{array}$ \\
\hline $\begin{array}{l}\text { Affiliation: } \\
{ }^{1} \text { Department of Christian } \\
\text { Spirituality, Church History } \\
\text { and Missiology, University of } \\
\text { South Africa, South Africa }\end{array}$ \\
\hline $\begin{array}{l}\text { Correspondence to: } \\
\text { Erna Oliver }\end{array}$ \\
\hline $\begin{array}{l}\text { Email: } \\
\text { olivee@unisa.ac.za }\end{array}$ \\
\hline $\begin{array}{l}\text { Postal address: } \\
\text { PO Box 392, UNISA 0003, } \\
\text { South Africa }\end{array}$ \\
\hline $\begin{array}{l}\text { Dates: } \\
\text { Received: } 23 \text { March } 2011 \\
\text { Accepted: } 21 \text { Oct. } 2011 \\
\text { Published: } 12 \text { Dec. } 2011\end{array}$ \\
\hline $\begin{array}{l}\text { How to cite this article: } \\
\text { Oliver, E., 2011, 'Violence: } \\
\text { The church is part of the } \\
\text { problem', Verbum et Ecclesia } \\
32(2) \text {, Art. \#510, } 5 \text { pages. } \\
\text { http://dx.doi.org/10.4102. } \\
\text { v32i2.510 }\end{array}$ \\
\hline $\begin{array}{l}\text { Note: } \\
\text { A shortened excerpt of this } \\
\text { paper was presented at the } \\
\text { conference on 'Violence in } \\
\text { the democratic South Africa: } \\
\text { A challenge for theology } \\
\text { and the churches' that } \\
\text { was hosted by the Centre } \\
\text { for Public Theology at the } \\
\text { University of Pretoria, } 10-12 \\
\text { August } 2010 \text {. }\end{array}$ \\
\hline
\end{tabular}

\section{Author:}

\section{Affiliation:}

${ }^{1}$ Department of Christian Spirituality, Church History and Missiology, University of

\section{Correspondence to:} Erna Oliver

\section{Email:}

Postal address:

PO Box 392, UNISA 0003, South Africa

\section{Dates:}

Received: 23 March 2011

Accepted: 21 Oct. 2011

How to cite this article: Oliver, E., 2011, 'Violence: problem', Verbum et Ecclesia 32(2), Art. \#510, 5 pages. http://dx.doi.org/10.4102

A shortened excerpt of this paper was presented at the conference on 'Violence in A challenge for theology and the churches' that was hosted by the Centre August 2010.
South African Christians are not only surrounded by violence, but actively participate in acts of violence, therefore contributing to the unacceptably high levels of anxiety and counterviolence across the country. Christian churches - both the institutions and their individual members - are accomplices to the current chaotic state of affairs in South Africa. Simply accepting and adapting to the standards and values of the society in which the church operates erases the signs and characteristics of the alternative community that Christians are supposed to be. Being no different from the rest of society deprives the churches of their power and influence on society.

The churches are caught up in a number of crises, causing them to be sidetracked from serious issues that need urgent attention. This calls for amelioration, which focuses not so much on creeds, but on deeds. Faith is supposed to change people and their behaviour. Challenging the way people behave, calling upon them to live without compromise and emphasising the need for introspection regarding the use of violence could bring creative transformation to both the church and society. To this end, this paper aimed to focus attention on the fact that the Christian churches in South Africa are not living up to their calling and, through its examination of the problem at hand, sound a call for introspection and action.

\section{Introduction}

According to Nationmaster statistics, South Africa tops the list of countries worldwide for assaults, AIDS deaths, gun violence, homicide and rape, per capita. South Africa is fourth on the list for robberies and drug offences and tenth for burglaries and the total number of crimes committed (Nationmaster 2009). Nearly half of the South African population lives in poverty and more than a quarter is unemployed (Statistics South Africa 2004). Undoubtedly, this has a negative influence on society and fuels acts of violence (Seedat et al. 2009:1011). Floors (cited in Coetzee 2005:188) describes violence as an unnecessary, excessive, hurtful and unlawful use of force and this is the definition that will be used for the purposes of this paper.

The culture of violence is not new to South Africa (cf. Nederduitsch Hervormde Kerk 2006; Shaw 2002). In fact, it is partly the fruit of an historical harvest (cf. Pillay 1991:1). The history of South Africa has been characterised by the occurrence of violence to a greater or lesser extent since the 17th century (Coetzee 2005:189). Over the years, violence generally has not been regarded as something that Christians should try to avoid. Instead, it was often justified from an ideological or theological perspective (Coetzee 2005:196) by both individuals and church leaders. When the churches eventually started to speak out against violence - mostly during the 20th century - it was usually directed against the violent behaviour of the 'other' or the 'enemy.' Churches did not formulate a unified response to the question of violence at any particular point in our history before 2006 (MacMaster 2005:201). In October 2006, representatives of a large number of Christian denominations gathered in Kempton Park and issued a declaration on violence and crime in South Africa (NHK 2006). In this declaration, it is said that 'the churches can no longer be spectators' and so nine issues are listed where the church needs to play an active role (NHK 2006). Yet, what is missing in the report is reflexive confirmation about the role that church members and the leaders themselves are playing and their contribution to the current situation. In addition, the undertones of helpless anxiety and victimisation that generally accompany violence and crime can be detected in this document, which may also undermine its goals.

Anxiety levels and acts of counter-violence are at unacceptably high levels in South Africa (Oliver 2011). Violent actions influence the lives of most South Africans on a daily basis and the graveness of this situation calls for urgent attention. In his paper on the nature and causes of violent crime in South Africa, David Bruce (2010:10), from the Centre for the Study of Violence and Reconciliation at the University of the Witwatersrand, Johannesburg, shows that common
(C) 2011. The Authors. Licensee: AOSIS OpenJournals. This work is licensed under the Creative Commons Attribution License. 
assaults stemming from arguments or anger-related issues (such as those many South African road users experience daily) form the broad base of the violence pyramid in South Africa. Acts of violence in this category are so common that most people are not aware of the fact that their behaviour is inappropriate or, in some cases, unlawful.

The example of road rage is chosen to serve as an expression of violent behaviour to illustrate the statement that the church, that is, both the institution and its individual members, are contributing to the current situation regarding violence in South Africa. Whilst there are no official statistics dealing with road rage, a survey conducted by the Automobile Association of South Africa (AA) (n.d.) amongst drivers in the Johannesburg area found that $63.3 \%$ of respondents reported experiencing aggression directed at them on a daily basis. A study conducted by market research company, Synovate, on behalf of Arrive Alive (2009) regarding road rage, showed that $51 \%$ of people interviewed reportedly experienced some aggressive or threatening behaviour directed at them on South African roads during 2009. In a previous study conducted in $2005,62 \%$ of those interviewed also added that they used aggressive behaviour, such as verbal insults or even physical assault, to express their anger and frustration whilst on the road (AA n.d.; Arrive Alive 2009).

It seems as if Christians are not only surrounded by violence, but often participate in violent acts and, sometimes, are not aware that their actions are violent in nature. For whilst the participants in these surveys were not asked about their religion, it could be suspected that there were Christians amongst them as the 2001 census stated that $79.8 \%$ of the South African population is Christian. Recently, during a Sunday morning service conducted in a suburban church in Pretoria, the congregation was asked to raise their hands if they had acted violently in traffic during the previous week. It seemed as if all hands were in the air. There is apparently no difference between the behaviour and actions of Christians or people who adhere to other religions and non-believers, as it cannot be assumed that all the acts of road rage (as well as all other acts of violence) are committed by the $16.5 \%$ of the population that indicated they have no religious affinity (Stats SA 2004:28).

There are thousands of Christian denominations in South Africa, each with its own characteristics and demography. About $87 \%$ of the White population group are Christians (Stats SA 2004:28). Unfortunately, more detailed statistics on this subject are not available (except for gender). Research for this preliminary investigation mainly involved the more 'traditional' Afrikaans-speaking churches and is therefore only an initial enquiry; wider and more detailed investigations will have to be undertaken on this subject. Questions that need to be asked in this regard are: why do Christian principles seem to fail in guiding the general behaviour of a large portion of South African Christians? Although the issue of violence is on the agendas of General Synods and formal declarations are made where churches commit themselves to work against violence, why does the situation on the ground not change? Why do church members participate in acts of violence?
The issue at hand seems to be very complex. From this initial study, two conclusions were drawn that can serve as starting points for unravelling this complex issue. Firstly, there are a number of major crises that are consuming the energy and focus of the churches. Secondly, Christians are not confronted with their participation in the situation and are therefore seemingly unaware of the fact that their behaviour needs to change before there can be any change in the overall situation.

\section{The church and violence}

The church is perhaps the only institution with the beliefs, literature, liturgy, practices, social structure and authority necessary to rescue people from violence and other deforming features of modern-day life (Charry 1994:166). Although the number of Christians in South Africa seems significant on paper, a large percentage of these Christians are nominal in their devotion or are only using the Christian faith as a label (Froise 2004:7-8). As such, their lives are not influenced and changed by their faith (Erasmus 2005:87). It seems as if the great tool of influence that is expected of all believers namely living a priestly life (Countryman 1999:153) - which is supposed to transform the church and its members into an alternative community (Samson 1983:10) that provides a window of hope for radical transformation in the hurting, bleeding, sick and violent society (cf. Whitley 1969), is not a priority for South African believers.

South Africans (or anyone else for that matter) cannot claim to be Christians when there is little or no attempt to live according to basic biblical principles of faith (cf. Oliver 2009a:77). Rick Warren (2005) said that the first Reformation was about beliefs, the second now needs to be about behaviour. Or, to phrase it differently, the first was about creeds, the second needs to be about deeds; the spotlight should fall on how to change social behaviour. In order to succeed in transforming people's lives and the situations in which they find themselves, the church must meet them at their point of need and in their existential reality. Where the issue of violence has been isolated for this investigation (this is, of course, not the only issue which contributes to the complexity of the situation), it should mean that Christians must be made aware of their own participation in the situation. Assumptions and actions need to be challenged constantly through various methods and at all levels in which the church operates - not only in declarations, synod minutes and other official documents. At the moment, this is not possible because the church is held hostage by false traditions and paradigms (Oliver 2009b:180) which divert its focus away from pressing issues such as these.

\section{The church and its crises}

More than 15 years ago, Rossouw (1995:75-93) posed 10 challenges to the South African theological society. Amongst other things, he pleaded for official attendance to political and business ethics and appealed that religion is a personal, but not a private, matter. Sadly, all the issues he mentioned remain major issues of concern threatening the integrity of 
the church and its members. One cannot help but wonder whether some of the current issues could have been avoided, and if the negative impact of violence could not have been turned into positive actions, had these challenges been heard and attended to years ago by the church as an organisation and by Christians as individuals (Oliver 2006b:1483).

It would be nearly impossible to expect the change that is currently needed from Christians to counter violence to be initiated from within the structures and organisation of the church. This is because of the number and intensity of other problems that are currently paralysing a large number of churches, which include (and this list is by no means complete):

- A lack of unity. The churches, in general, confess unity in faith through the Confession of Nicaea (Oliver 2011:40), but tend to see their syncretistic civil religion (NiederHeitmann 2003:185) and themselves as the sole keepers of the truth (Oliver 2007:34). The Tussen Kerklike Raad [Inter-Church council] that was originally constructed in South Africa to promote unity, concluded that it was 'not realistic' to push for unity and shifted its focus to cooperation (Oliver 2011:47).

- An urgent need for competent spiritual leadership (Oliver 2007:29) in order to quash internal power struggles and disrupting politics. To a large extent the churches are male dominant (Oliver 2008), frozen in their hierarchical systems (Oliver 2009a:68) and dependency paradigm (Oliver 2009b:169). It seems as if the present forms of ministry are more concerned with maintaining dependence on religious leaders than promoting responsibility, gifts and the priesthood of all believers, because the former is nonthreatening to both church leadership and the institutions that often try to expand their control over people to accumulate wealth and power (cf. Graham 1983:49; Riesebrodt 2000:21).

- The different theological movements and their hybrids within the church (Steyn 2006:661-676). Christianity seems to have become a popular consumer article (Oliver 2007:29), available to be picked according to the needs and preferences of each individual. By the end of the 20th century, the conclusion was officially drawn in one of these churches that there is no consensus on the status of the Bible as absolute authority in the lives of Christians any more (Britz 2002:364).

- An identity crisis (Steyn 2005:551), which started with the reversal of the theological sanctification of apartheid and led to a huge loss in credibility, status and power for some churches. This resulted in such a significant level of trauma for many of these churches that, to a large extent, they were rendered lame and mute (Steyn 2005:551). Complicating this even further, is the fact that the traditional apartheid mindset is still alive and well in the minds and actions of a large group of Afrikaner Christians (Botha 2008).

- An extremely high loss of church membership in the three traditional Afrikaans-speaking churches (the Dutch Reformed Church [DRC], the Gereformeerde Kerke in Suid-Afrika [GKSA] and the NHK; cf. Oliver 2006a). Yet, the rise in membership of charismatic churches over the last two decades shows that believers are not abandoning their faith. However, for those churches struggling with decreasing numbers the tendency has been to focus on survival and concentrate their energy on internal matters and abandon the great calling to evangelise the world in order to survive.

From this, the conclusion can be drawn that nothing short of a Copernican revolution of the mind and heart could change the heretical state of affairs in South Africa today (Banks \& Stevens 1997).

\section{The problem of violence}

Huber (1996) distinguishes between the 'Olympic model' and the 'Jesus model' as used by Christian churches in general. The Olympic model orientates itself towards the flawless, youthful achieving victor. It is basically a male-orientated model and has a particularly good chance of succeeding in a society dominated, to a large extent, by male values and interests. On the other hand, the Jesus model stresses that everybody - irrespective of age, gender, citizenship, religion, achievement, or merit - is due the same dignity, precisely in the face of our vulnerability and mortality. This model draws us into a cycle of continuous perspective change and action (Huber 1996:45) - which exactly where the churches need to be. However, in the introduction to Huber's work on violence, Berrigan (1996:xi) says that the Jesus model is being violated by the churches. It tends to sanction the values and norms emphasised in the community (Whitley 1969:14). As a social and personal force, the Christian church has become a dependant variable: it does not originate; it reacts. It does not denounce; it adapts. It does not set forth new modes of conduct and sensibility; it imitates (cf. Mills 1958:166). This can also be said to be the case in South Africa currently. The church has lost its uniqueness and is looking increasingly like the secular world surrounding it (Buitendag 2008:129).

The natural tendency during times of uncertainty, crisis and anxiety, is to hold onto tradition and other known comforts. It is also in times of crisis and change that the seedbeds of new growth are ready to be cultivated. This is the time to invent, abolish, revitalise and reinterpret in order to confirm, reform or even revolutionise personal behavioural patterns (cf. Riesebrodt 2000:24). And it is at this point where the South African churches should act and persist in their actions.

An online search for guiding material on the issue of violence proved to be of little help in this regard. For example, the Apostolic Faith Mission of South Africa (http://www.afmags.org) provides a selection of 'important documents' which can be downloaded, covering issues such as cremation, surrogate motherhood, tobacco and unveiling of a tombstone, but does not offer any guidelines relating to the use of violence in Christian life. Similarly, the GKSA (http:/ / www. gksa.org) provides downloadable documentation on issues such as the death sentence, HIV and AIDS and disadvantaged communities, but nothing on violence. Amongst the documents of the NHK, only the 2006 declaration (cited 
above) refers to the issue of violence, whilst the DRC website (http://www.ngk.org.za) contains only three declarations against violence and a 2006 news release which confirms the complexity of the issue and urges local communities to take responsibility for the problem at ground level.

South African Christians urgently must change their perception on violence - including that which avails them to believe they are only victims, or that it is all right for them to participate in, or counteract, violent behaviour). However, it is extremely important to remember that people can only stop acting violently if their thoughts and perceptions are changed before they are confronted by an aggravating situation.

\section{Faith and change}

Faith changes people, not structures or institutions. Change comes through repeated, consistent and sustainable positive actions. Denis Ackermann (cited in Camp 1994:165) says: 'I never heard a sermon on rape'. Well, neither have I - nor on domestic violence, hate speech, road rage, or any other kind of violence that Christians, church leaders and church members regularly commit. The general trend is either to marginalise sin in general (Conradie 2005) or to shine the spotlight only on a few chosen sins. In general, believers are not confronted constantly by the church leaders about their violent behaviour. They are not asked to confess their violent actions and their progress in behavioural change is not monitored. Yet, is constant vigilance not one way of ensuring that Christian behaviour is directed towards consistent and positive change? By using constant confrontation to focus on this issue, people would become aware of, and convinced that, their actions and perceptions are contributing to the current situation. Surely the aim of all churches is to help Christians to grow into leadership skills, gifts and roles in the church, living the example of Christ and proclaiming the Gospel with their whole life (Frank \& Pearson 1998:8-9)?

Throughout history, Christian behaviour has managed to change the world, sometimes for the better (cf. Hill 2005; Schmidt 2004), but often for worse (church history is in many instances a history of violence). The early Church began by changing the thoughts and perspectives of groups of people and when enough people were changed and started to act differently, their influence started to have an impact on their communities and eventually on society. This is a clear example of how faith changes people by changing their behaviour. A changed behavioural pattern can contribute to bringing change to South African Christianity. However, Steyn (2005) is correct to side with Meiring (1980:207-215) in warning against mere cosmetic changes when open heart surgery is required. This is one of the problems that we experience when we look at current attempts to pull the church back on track (Oliver 2009b).

\section{Conclusion}

Violence, defined as any unnecessary, excessive, hurtful and unlawful use of force, should not be a problem in a predominantly Christian society such as South Africa.
However, statistics show that this is not the case. 'They [the churches] could play an extremely important role in healing and reconciling our society, and mending the deep divisions among people, but they are not taking their role seriously' (Villa-Vicencio, cited in Larsen 2000). Christians ought to have a positive and constructive influence on, as well as the power to bring positive change to, society.

Currently, however, there is not much that differentiates Christians from other non-Christian South Africans when it comes to participation in acts of violence and counterviolence. On the one hand, this is a result of the fact that traditionally South African history does not identify violence as a sin but, instead, tends to justify it either from an ideological or a theological perspective. Thus, there is no real understanding that the churches themselves (both leaders and members) are not only the victims but also the participants and, as such, must be held accountable for their actions. On the other hand, the churches and their members are caught in a number of crises that are so extensive that they cannot contribute actively towards a positive resolution of the problem on violence. This results in the issuing of documents (such as the 2006 declaration) where both the government and the private sector are called upon to bring about change, but where there is no real confession and commitment from the side of individual Christians to engage in intense introspection and to actively, persistently and directly confront all members and leaders of their churches to refrain from violent behaviour and to start living and promoting change. Christians should not be afraid to address controversial and sensitive issues (Lehmann 2002:591) such as these with fellow Christians: the Jesus model must draw us all into the continuous changing of perspective and actions.

The tool that must be implemented to change perceptions and actions is faith. Faith, and not tradition or history or the doctrine of the church or personal circumstances, must set the boundaries for all Christian actions and provide the rules by which to live. Faith transforms people and transformed people should act as leaders and agents of change. Church services, meetings and conferences, such as the one held at the University of Pretoria on violence (see the Note above), could all act as growth points to activate change in order to alter the perceptions and actions of people who can spread the word and action, creating an alternative community. There should be a continuation and expansion of the initial steps in the Church of equipping, training, exchanging and monitoring the progress and impact of violence, both on individuals and the Church as an organisation. Individual church members must be confronted regarding their part in creating the current situation. Formal church policies and focused ministry actively must seek to promote a positive, constructive outcome. Christians should be educated and trained regarding the role they need to play in society. The churches as institutions need to provide guidelines, in no uncertain terms, as to where Christians stand in society and how they ought to behave. Church leaders should be living examples, encouraging others to follow suit. 
There is an alternative to violence. Christians know this and so should live this. They are the church to others. 'The miracle of the church's story is that after all its mistakes, bewildering transformations and entanglements in human bitterness, it is still there' (MacCulloch 1987:11). It is up to the Christian population of South Africa to strengthen their faith and change their circumstances for the better.

\section{Acknowledgements Competing interests}

The author declares that she has no financial or personal relationship(s) which may have inappropriately influenced her in writing this paper.

\section{References}

Arrive Alive, 2009, Road rage, viewed 16 August 2011, from http://www.arrivealive. co.za/pages.aspx?i=2232

Automobile Association of South Africa, n.d., Road rage, don't get drawn in, viewed 16 August 2011, from http://www.aa.co.za/content/131/road-rage-dont-getdrawn-in/

Banks, R. \& Stevens, P. (eds.), 1997, Complete book of everyday Christianity, viewed 27 May 2009, from http://www.urbana.org/complete-book-of-everyday-christianity/ laity

Berrigan, D., 1996, 'Foreword', in W. Huber, Violence. The unrelenting assault on human dignity, transl. R.C.L. Gritsch, Fortress Press, Minneapolis.

Botha, B., 2008, The Afrikaner's emancipation. Freeing South Africans from their apartheid mindset, iUniverse, New York.

Britz, R.M., 2002, 'Twee standpunte oor die Skrif ... en 'n dilemma vir die NG Kerk [Two statements regarding the Bible .... and a problem for the DR Church]', Nederduits Gereformeerde Teologiese Tydskrif 43(3\&4), 354-367.

Bruce, D., 2010, "'The ones in the pile were the ones going down". The reliability of violent crime statistics', SA Crime Quarterly 31 (March 2010), 9-17.

Buitendag, J., 2008, 'Ecclesia reformata semper reformanda - Die ongemaklike eis [The Reformed church always reforming - The uncomfortable demand]', HTS Teologiese Studies/Theological Studies 64(1), 123-138.

Camp, S.T., 1994, 'Why have you been silent? The church and the abortion ban in South Africa', Columbia Journal of Gender and Law 4(2), 143-172.

Charry, E.T., 1994, 'Raising Christian children in a pagan culture', Christian Century 16 February, 166

Coetzee, C.F.C., 2005, 'Violence in post-apartheid South Africa and the role of Church and Theology', in D. Van Keulen \& M.E. Brinkman (eds.), Christian faith and violence, vol. 1., pp. 188-2002, (Studies in Reformed Theology 10), Meinema, Zoetermeer.

Conradie, E.M., 2005, 'Towards an ecological reformulation of the Christian doctrine of sin', Journal of Theology for Southern Africa 122, July, 4-22.

Countryman, L.W., 1999, Living on the border of the Holy. Renewing the priesthood of all, Morehouse, Harrisburg.

Erasmus, J., 2005, 'Who are the people with no religion?', in J. Symington (ed.), SA Christian handbook 2005/2006, pp. 87-101, Lux verbi, Wellington.

Frank, P. \& Pearson, G., 1998, Too little - Too late! Children's evangelism beyond crisis, Grove Books, Cambridge.

Froise, M., 2004, 'Is Christianity in South Africa a label or a spiritual and ethnical value system? A study of Christian adherence in the city of Welkom', unpublished DTh thesis, Department of Missiology, University of South Africa, Pretoria.

Graham, P., 1983, 'Looking towards 2001 AD', The papers and synopsis of the discussions relating to the symposium Sunday school 2001 AD arranged by the Christian Education Commission of SANNSSA, Johannesburg, South Africa, 02-04 August, pp. 45-50.

Hill, J., 2005, What has Christianity ever done for us?, Hudson, Oxford.

Huber, W., 1996, Violence. The unrelenting assault on human dignity, transl. R.C.L. Gritsch, Fortress Press, Minneapolis.

Larsen, B., 2000, 'Suffering from post-apartheid fatigue', Christianity Today August, viewed 23 March 2011, from http://www.christianitytoday.com/ct/article_print. html?id=15870
Lehmann, H., 2002, 'The history of twentieth century Christianity as a challenge for historians', Church History 71(3), 585-599. http://dx.doi.org/10.1017/ S0009640700130288

MacCulloch, D., 1987, Groundwork of Christian history, Epworth, London.

MacMaster, L.L.M., 2005, 'Violence and Christian faith: A (never-ending) spiral of violence? Trying to shake off our violent past in South Africa', in D. Van Keulen \& M.E. Brinkman (eds.), Christian faith and violence, vol. 1., pp. 201-218, Meinema, Zoetermeer.

Meiring, P., 1980, 'Eksklusief of Ekumenies? [Exclusive or ecumenical?]' in E. Botha, D. Steenberg, J. Taljaard, B. Van der Walt \& K. Van der Walt (eds.), Venster op die kerk. 20 lidmate oor die reformasie van die kerk in die jare 80, pp. 207-215, Instituut vir Reformatoriese Studies, Potchefstroom.

Mills, C.W., 1958, The causes of world war three, Simon and Schuster, New York.

Nationmaster, 2009, Crime statistics by country, viewed 20 July 2010, from http:// www.nationmaster.com/cat/cri-crime

Nieder-Heitmann, J.H., 2003, 'The missionary challenge of Christendom and modernity in South Africa: A Dutch Reformed account', International Review of Mission XCII (365), 178-191.

Nederduitsch Hervormde Kerk, 2006, Verklaring deur die kerkleiers oor geweld en misdaad in Suid-Afrika [Declaration by Church leaders regarding violence and crime in South Africa], viewed 20 July 2010, from http://www.nhk.co.za.uploads/ filles/oms4a.doc

Oliver, E., 2006a, 'Sunday school: Past and present', Studia Historiae Ecclesiasticae 32(1), 117-134.

Oliver, E., 2006b, 'Afrikaner spirituality: A complex mixture,' HTS Teologiese Studies/ Theological Studies 62(4), 1469-1487.

Oliver, E., 2007, 'Thoughts on writing Afrikaner church history,' Studia Historiae Ecclesiasticae 33(1), 23-40.

Oliver, E., 2008, 'Vrouepredikante in die Nederduitsch Hervormde Kerk van Afrika: 'n Opdraande stryd [Women as ministers of religion in the Dutch Reformed Church of Africa: An uphill struggle]', Studia Historiae Ecclesiasticae 34, suppl. ser., 213-233.

Oliver, E., 2009a, 'His blood I will require at your hand: The issue of theological education for the laity', Studia Historiae Ecclesiasticae 35, suppl. ser., 67-79.

Oliver, E., 2009b, 'Suid-Afrikaanse Calvinisme onder die loep [South African Calvinism under investigation]', Studia Historiae Ecclesiasticae 35(2), 169-182.

Oliver, E., 2011, 'Is Ecumenism an option?', Studia Historiae Ecclesiasticae 37(1), 39-57.

Pillay, G.J., 1991, 'In quest of a nation: Some historical pitfalls and stumbling blocks', in W.S. Vorster (ed.), Building a new nation: The quest for a new South Africa, pp. 1-14, Unisa, Pretoria.

Riesebrodt, M., 2000, Secularization and the global resurgence of Religion, viewed 05 March 2010, from http://www.sscnet.ucla.edu/soc/groups/ccsa/riesebrodt.pdf

Rossouw, G.J. (ed), 1995, 'Theology in a postmodern culture: Ten challenges,' in G.J. Rossouw (ed.), Life in a postmodern culture, pp. 75-93, Human Sciences Research Council, Pretoria.

Samson, R., 1983. 'The church in South Africa and Sunday school today', The papers and synopsis of the discussions relating to the symposium Sunday school 2001 aD arranged by the Christian Education Commission of SANNSSA, Johannesburg, South Africa, 02-04 August, pp. 9-15.

Schmidt, A.J., 2004, How Christianity changed the world, Zondervan, Grand Rapids.

Seedat, M., Van Niekerk, A., Jewkes, R., Suffla, S. \& Ratele, K., 2009, 'Violence and injuries in South Africa: Prioritising an agenda for prevention,' Health in South Africa 5, Lancet 374(9694), 1011-1022, viewed 19 September 2009, from http:// dx.doi.org/10.1016/S0140-6736(09)60948-X

Statistics South Africa, 2004, Primary tables, Stats SA, Pretoria.

Shaw, M., 2002, Crime and policing in post-apartheid South Africa: Transforming under fire, Hurst \& Company, London.

Steyn, G.J., 2005, 'Die NG Kerk se identiteitskrisis. Deel 1: Aanloop, terreine van beïnvloeding en reaksies [The identity crisis of the DR Church. Part 1: Run-up, areas of influence and reactions]', Nederduits Gereformeerde Teologiese Tydskrif $46(3 \& 4), 550-559$

Steyn, G.J., 2006, 'Die NG Kerk se identiteitskrisis. Deel 2: Huidige bewegings, tendense of mutasies [The identity crisis of the DR Church. Part 2: Current movements, tendencies of mutations]', Nederduits Gereformeerde Teologiese Tydskrif 47(3\&4), 661-676.

Warren, R., 2005, 'Rick Warren's second reformation', presented with Tony Campolo and Jimmy Carter at the 19th Congress of the Baptist World Alliance, Birmingham, 27-31 July, viewed 07 November 2011, from http://www.lighthousetrailsresearch. com/rw2ndreformation.htm

Whitley, O.R., 1969, The Church: Mirror or window? Images of the church in American society, The Bethany Press, St. Louis. 